\title{
Meningkatkan Kemampuan Bekerja dengan Grafik melalui Pembelajaran Kinematika
}

\author{
Nurul Hidayah ${ }^{1}$, Sutopo $^{1}$, Hari Wisodo ${ }^{1}$ \\ ${ }^{1}$ Pendidikan Fisika-Universitas Negeri Malang
}

\begin{tabular}{|c|c|}
\hline INFO ARTIKEL & ABSTRAK \\
\hline Riwayat Artikel: & $\begin{array}{l}\text { Abstract: This research examines the increase of students' ability in working with } \\
\text { graph. This research is conducted by involving } 58 \text { students in class X SMA Negeri } 5\end{array}$ \\
\hline $\begin{array}{l}\text { Diterima: 05-03-2019 } \\
\text { Disetujui: } 13-03-2019\end{array}$ & $\begin{array}{l}\text { Malang as the subjects. Students are given kinematics learning by making models of } \\
\text { various representations including graphics. The ability of students are assessed using }\end{array}$ \\
\hline $\begin{array}{l}\text { Kata kunci: } \\
\text { student's graph ability; } \\
\text { representation; } \\
\text { kinematics; }\end{array}$ & $\begin{array}{l}\text { observed from the average score pretest and posttest. The analysis shows that there is a } \\
\text { significant increase }(\mathrm{p}=0.00) \text { with the results of the N-Gain calculation of } 0.25 \\
\text { including the medium category. Students are able to change the understanding of graph } \\
\text { after learning even though the WYSIWYG effect is still very influential on the way } \\
\text { students interpretation graph. }\end{array}$ \\
\hline
\end{tabular}

kemampuan grafik siswa; representasi; kinematika

\begin{abstract}
Abstrak: Penelitian ini mengkaji peningkatan kemampuan siswa bekerja dengan grafik. Penelitian dilakukan dengan subjek 58 siswa kelas X SMA N 5 Malang. Siswa diberikan pembelajaran kinematika dengan membuat model berbagai representasi termasuk grafik. Kemampuan siswa diukur menggunakan soal-soal multiple choice dalam format grafik. Peningkatan kemampuan siswa ditinjau dari skor rata-rata pretest dan posttest. Analisis menunjukkan ada peningkatan signifikan $(p=0,000)$ dengan hasil perhitungan $\mathrm{N}$-Gain sebesar 0,25 termasuk kategori sedang. Siswa mampu mengubah pemahaman tentang grafik setelah pembelajaran meskipun efek WYSIWYG masih sangat berpengaruh pada cara siswa menginterpretasikan grafik.
\end{abstract}

\author{
Alamat Korespondensi: \\ Nurul Hidayah \\ Pendidikan Fisika \\ Universitas Negeri Malang \\ Jalan Semarang 5 Malang \\ E-mail: nurul.hidayah9426@gmail.com
}

Kemampuan bekerja dengan grafik sangat diperlukan untuk memahami konsep secara mendalam dan mengembangkan kemampuan umum siswa (McDermott dkk., 2006; McPadden \& Brewe, 2017; Susac dkk., 2018). Grafik menjadi bagian penting dalam komunikasi ilmiah. Sebagai sarana komunikasi, grafik dapat digunakan untuk menyampaikan ide maupun menginterpretasikan data (Nixon dkk., 2016; Zucker dkk., 2013). Grafik juga dimanfaatkan dalam penyajian data dari hasil kerja laboratorium (McDermott dkk., 2006).

Kajian penelitian tentang grafik mengungkap kesulitan dalam membaca dan menginterpretasikan grafik (Beichner, 2014; Bollen dkk., 2016; Ceuppens dkk., 2019; McDermott dkk., 2006; Nguyen \& Rebello, 2011; Wemyss \& van Kampen, 2013). Kesulitan siswa dalam menginterpretasikan grafik digolongkan menjadi dua kategori, yakni siswa kesulitan untuk menghubungkan grafik ke konsep fisik dan siswa kesulitan menghubungkan grafik ke fenomena yang sesungguhnya (McDermott dkk., 2006). Pada studi lain siswa kesulitan dalam memaknai kemiringan dan luasan area di bawah kurva (Ceuppens dkk., 2019; Planinic dkk., 2012; Susac dkk., 2018; Wemyss \& van Kampen, 2013). Siswa cenderung menggunakan ordinat untuk menyelesaikan pertanyaan tentang kemiringan (Beichner, 2014).

Dalam menafsirkan grafik siswa melihat grafik sebagai gambar nyata suatu keadaan. Sebagai contoh siswa diberikan sebuah grafik kecepatan terhadap waktu dari seseorang yang bersepeda di area bukit. Pada grafik terdapat kurva yang melengkung menjangkau ketinggian tertentu sehingga kurva melengkung seperti bentuk bukit. Siswa akan menganggap ketinggian tersebut sebagai bukit yang sesungguhnya (Elby, 2000). Visual objek yang dilihat oleh siswa sangat memengaruhi informasi yang diperoleh. Seperti yang disampaikan (Beichner, 2014). Penafsiran siswa dalam memaknai grafik memunculkan kesalahan seperti bentuk garis atau kurva dalam grafik sebagai bentuk gerak objek. Pada kasus ini dikenal dengan istilah what you see is what you get (WYSIWYG) (Elby, 2000).

Penelitian lain menyatakan siswa yang memiliki pengetahuan grafik matematika lebih baik tidak menjamin keberhasilan mereka dalam menyelesaikan masalah grafik fisika atau konteks yang lain (Planinic dkk., 2012). Siswa mengalami kesulitan dalam mentransfer ide matematika yang dimiliki untuk disiplin ilmu yang lain (Christensen \& Thompson, 2012). Sebagai contoh siswa mengenal persamaan garis lurus dalam matematis termasuk menentukan gradien. Ketika siswa 
dihadapkan pada permasalahan pada fisika siswa tidak lagi menggunakan ide matematis untuk menyelesaikan soal. Pada konteks lain siswa lebih mudah memahami grafik di matematika karena siswa sangat mengenal dua koordinat $x$ dan $y$, sedangkan pada fisika sumbu koordinat dapat diubah menjadi $x$ - $t, v-t$ maupun $a$ - $t$. Seringkali permasalahan grafik dikaitkan dengan kemampuan konsep matematis yang dimiliki siswa.

Grafik pada kinematika mencakup grafik posisi, kecepatan, dan percepatan terhadap waktu (Christensen \& Thompson, 2012). Pada kinematika grafik menjadi aplikasi dari pengetahuan grafik dalam matematika. Grafik yang dibuat pada kinematika berbasis keadaan yang lebih natural dari gerakan suatu objek (Hale, 2000). Siswa mengalami kebingungan jika variabel dalam grafik diubah. Sebagai contoh siswa diminta untuk menentukan grafik percepatan terhadap waktu sesuai sajian grafik kecepatan terhadap waktu. Kebingungan ini mengakibatkan siswa tidak menggambarkan dengan tepat antar keduanya (Beichner, 2014).

Pada penelitian ini telah didesain pembelajaran kinematika untuk meningkatkan kemampuan grafik. Pembelajaran kinematika yang dilakukan meliputi langkah-langkah yang diawali dengan pemberian fenomena, mengidentifikasi fenomena untuk memperoleh data, kemudian dilanjutkan dengan pembentukan model. Fenomena yang disajikan akan memberikan data posisi dan waktu selama benda bergerak. Data yang diperoleh siswa selanjutnya dibentuk ke dalam grafik posisi terhadap waktu, kecepatan terhadap waktu, dan percepatan terhadap waktu. Selama pembentukan grafik siswa dilatihkan untuk terbiasa memperoleh data terlebih dahulu. Setelah data didapatkan siswa dibiasakan untuk menentukan sumbu koordinat vertikal dan horizontal agar lebih mudah dalam membuat grafik. Artikel ini difokuskan pada efektivitas pembelajaran dalam meningkatkan kemampuan siswa bekerja dengan grafik.

\section{METODE}

Pelaksanaan penelitian melibatkan subjek penelitian sebanyak 58 siswa SMA N 5 Malang yang berada di kelas X dan sedang menempuh materi kinematika. Kemampuan siswa bekerja dengan grafik diuji dengan soal pilihan ganda. Siswa diberikan sembilan soal terkait grafik posisi, kecepatan dan percepatan terhadap waktu (Tabel 1). Keseluruhan butir soal merupakan soal yang valid dengan validitas antara $0,177-0,479$. Selain memilih jawaban yang benar, siswa diminta untuk memberikan alasan mengapa memilih opsi tersebut.

Tabel 1. Isi Butir Soal Grafik

\begin{tabular}{|c|c|c|}
\hline Jenis Grafik & No. Soal & $\begin{array}{lc}\text { Isi Butir Soal } \\
\end{array}$ \\
\hline \multirow{2}{*}{$\begin{array}{l}\text { Grafik posisi terhadap } \\
\text { waktu }\end{array}$} & 1 & $\begin{array}{l}\text { Disajikan grafik kecepatan terhadap waktu dari sebuah benda yang bergerak. Siswa diminta } \\
\text { menentukan grafik posisi terhadap waktu berdasarkan analisis grafik kecepatan terhadap waktu. }\end{array}$ \\
\hline & 2 & $\begin{array}{l}\text { Disajikan grafik posisi terhadap waktu dari seseorang yang bergerak. Siswa diminta menganalisis } \\
\text { arah gerak, kecepatan dan perpindahan sesuai dengan grafik. }\end{array}$ \\
\hline \multirow{5}{*}{$\begin{array}{l}\text { Grafik kecepatan } \\
\text { terhadap waktu }\end{array}$} & 3 & $\begin{array}{l}\text { Disajikan tabel yang berisi data posisi dan waktu sebuah benda yang bergerak lurus. Siswa diminta } \\
\text { untuk menentukan grafik kecepatan terhadap waktu berdasarkan data pada tabel. }\end{array}$ \\
\hline & 4 & $\begin{array}{l}\text { Disajikan grafik kecepatan terhadap waktu dari tiga truk yang bergerak lurus. Siswa diminta untuk } \\
\text { menganalisis percepatan ketiga benda. }\end{array}$ \\
\hline & 5 & $\begin{array}{l}\text { Disajikan grafik kecepatan terhadap waktu dari benda yang bergerak. Siswa diminta untuk } \\
\text { menganalisis perpindahan, kelajuan dan arah gerak. }\end{array}$ \\
\hline & 6 & $\begin{array}{l}\text { Disajikan grafik kecepatan terhadap waktu dari benda yang bergerak. Siswa diminta menentukan } \\
\text { percepatan di waktu tertentu sesuai dengan grafik. }\end{array}$ \\
\hline & 7 & $\begin{array}{l}\text { Disajikan deskripsi gerak vertikal sebuah benda. Siswa diminta menentukan grafik kecepatan } \\
\text { terhadap waktu yang sesuai dengan deskripsi. }\end{array}$ \\
\hline \multirow{2}{*}{$\begin{array}{l}\text { Grafik percepatan } \\
\text { terhadap waktu }\end{array}$} & 8 & $\begin{array}{l}\text { Disajikan tabel berisi data posisi terhadap waktu dari benda yang bergerak lurus. Siswa diminta } \\
\text { menentukan grafik percepatan terhadap waktu sesuai data pada tabel. }\end{array}$ \\
\hline & 9 & $\begin{array}{l}\text { Disajikan grafik percepatan terhadap waktu dari benda yang bergerak. Siswa diminta menganalisis } \\
\text { gerakan benda sesuai dengan grafik. }\end{array}$ \\
\hline
\end{tabular}

Analisis data dilakukan berdasarkan respons siswa menjawab soal-soal yang diberikan ketika pretest dan posttest. Untuk melihat perubahan siswa, skor pretest dan posttest dianalisis dengan menggunakan normalized gain (Hake, 2008). Data kualitatif yang diperoleh dari alasan siswa akan dikelompokkan sesuai dengan alasan yang sejenis. Analisis jawaban siswa digunakan untuk mengetahui pergeseran pemikiran siswa dalam menjawab soal setelah diterapkan pembelajaran.

\section{HASIL}

Pembelajaran yang dilaksanakan pada materi kinematika memuat adanya kemampuan representasi berupa grafik. Pembelajaran ini dilakukan untuk membantu siswa dalam meningkatkan kemampuan bekerja dengan grafik yang diukur dengan instrumen tes. Tes tersebut diberikan sebagai pretest dan posttest untuk melihat adanya peningkatan kemampuan siswa bekerja dengan grafik. Hasil analisis statistik deskriptif nilai siswa pada pretest dan posttest tersaji pada tabel 1. 
Tabel 1. Statistik Deskriptif Nilai Siswa

\begin{tabular}{lcc}
\hline Statistik & Pretest & Posttest \\
\hline Minimum & 0 & 22 \\
Maximum & 56 & 67 \\
Mean & 23,98 & 43,03 \\
Standard Deviasi & 15,88 & 14,39 \\
Skewness & 0,471 & 0,049 \\
\hline
\end{tabular}

Perhitungan statistik deskriptif nilai pretest dan posttest sangat jelas menunjukkan adanya perubahan siswa yang semakin meningkat. Hasil skewness pada tabel 1 menunjukkan data tersebut dapat diasumsikan bahwa setidaknya berdistribusi mendekati normal karena berada pada rentang -1 sampai 1 (Morgan, Leech, Gloeckner, \& Karen C. Barrett, 2004). Selanjutnya dilakukan uji beda dengan paired sample t-test yang hasilnya menunjukkan antara skor pretest dan pottest terdapat perbedaan yang signifikan. Peningkatan perolehan siswa dari pretest ke posttest dapat dilihat dari hasil N-Gain ternormalisasi sebesar 0,25 termasuk kategori sedang (Hake, 2008) dengan Cohen's d-effect size 1,26 artinya kekuatannya sangat kuat (Morgan dkk., 2004). Peningkatan yang signifikan juga dapat dilihat berdasarkan persentase jumlah siswa yang menjawab benar saat pretest dan posttest seperti disajikan tabel 2.

Tabel 2. Persentase Siswa Menjawab Benar

\begin{tabular}{lcc}
\hline \multirow{2}{*}{ Jenis Grafik } & \multicolumn{2}{c}{ Jumlah Siswa Menjawab Benar (\%) } \\
\cline { 2 - 3 } & Pretest & Posttest \\
\hline Posisi terhadap waktu & $15 \%$ & $56 \%$ \\
Kecepatan terhadap waktu & $27 \%$ & $37 \%$ \\
Percepatan terhadap waktu & $16 \%$ & $47 \%$ \\
\hline
\end{tabular}

\section{PEMBAHASAN}

Pembelajaran yang diterapkan memberikan hasil positif untuk meningkatkan kemampuan siswa dalam bekerja dengan grafik. Siswa dapat menunjukkan pergeseran pemahaman dari pretest ke posttest menjadi lebih baik. Untuk lebih jelasnya akan diuraikan sesuai jenis grafik sebagai berikut.

\section{Grafik Posisi terhadap Waktu}

Butir soal yang memuat grafik posisi terhadap waktu dalam gerak lurus disajikan pada soal nomor 1 dan 2. Kedua butir soal tersebut menunjukkan adanya peningkatan untuk jumlah siswa yang menjawab benar (Tabel 2). Sebagai contoh Gambar 1 merupakan soal grafik posisi terhadap waktu yang diberikan pada siswa.

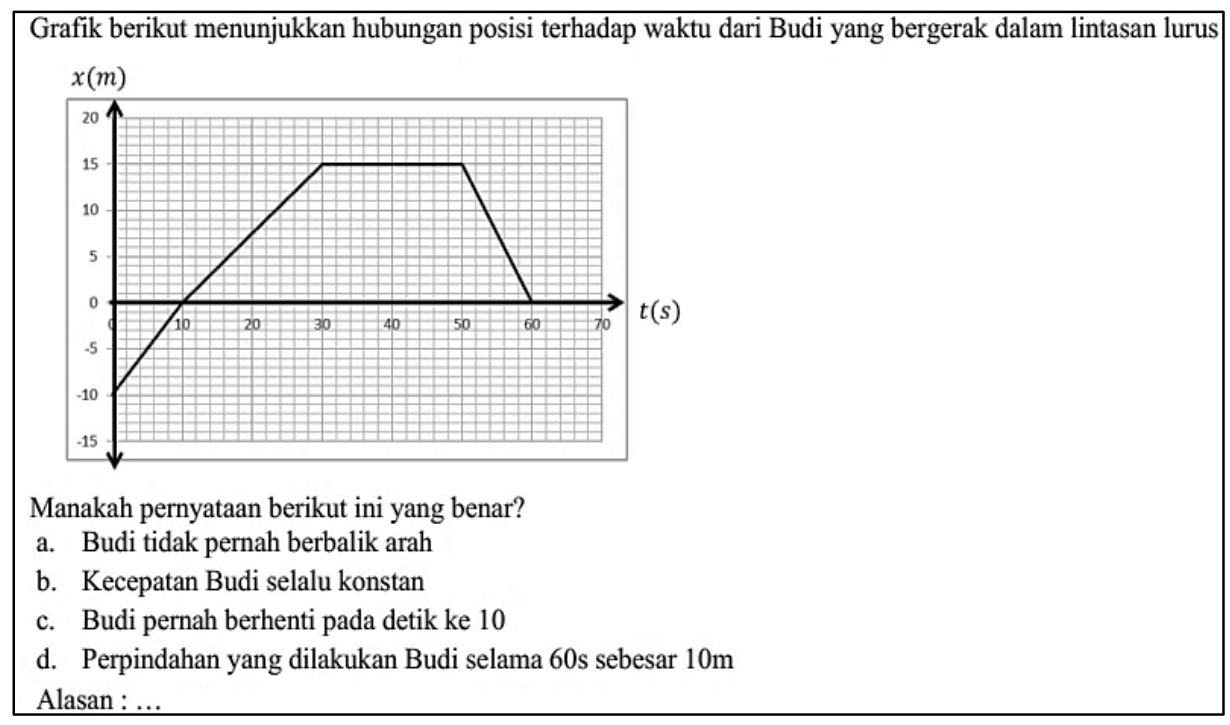

Gambar 1. Butir soal yang memuat grafik posisi terhadap waktu

Pada soal yang disajikan gambar 1 jumlah siswa menjawab benar pilihan D saat pretest hanya sembilan orang (16\%). Kesembilan siswa tersebut tidak memberikan alasan dalam menjawab soal. Sehingga tidak dapat diketahui dengan pasti bagaimana pemikiran siswa menyelesaikan soal tersebut. Sebaran pilihan jawaban siswa yang memilih opsi A sebesar $19 \%$, opsi B 7\%, opsi C 47\%, serta siswa tidak menjawab sebanyak 12\%. Opsi pilihan jawaban terbanyak yang dipilih siswa adalah 
opsi C dengan jumlah 27 siswa (47\%). Sebanyak empat belas siswa memberikan alasan bahwa "grafik dimulai dari negatif ke positif sehingga terjadi perubahan arah gerak". Tiga siswa memberikan alasan "di saat $t=10$ benda diam karena berada di $x=0 m$ ". Pemahaman pada siswa yang menjawab salah pada pretest terpengaruh pada efek WYSYWIG (Elby, 2000), serta kesalahan memaknai tanda positif dan negatif untuk grafik posisi terhadap waktu. Setelah dilakukan pembelajaran siswa mulai menggeser pilihan jawaban ke opsi jawaban yang benar yang dapat dilihat pada tabel 3.

Tabel 3. Tabulasi Silang Pergeseran Jawaban Siswa

\begin{tabular}{llllllc}
\hline & \multicolumn{7}{c}{ Posttest } \\
\hline Pretest & A & A & B & C & D* & Total Pretest \\
& B & 0 & 0 & 9 & 2 & 11 \\
& C & 0 & 1 & 3 & 0 & 4 \\
& D* & 1 & 0 & 20 & 6 & 27 \\
& TM & 0 & 0 & 3 & 6 & 9 \\
\hline & 0 & 0 & 1 & 6 & 7 \\
\hline
\end{tabular}

Pilihan jawaban yang benar mengalami peningkatan dari 9 menjadi 20 orang. Siswa yang menjawab benar memberikan alasan "perpindahan diperoleh dari posisi akhir dikurangi posisi awal". Siswa mampu menggunakan persamaan perpindahan yakni $\Delta \vec{x}=x_{f}-x_{i}$ untuk menyelesaikan soal. Sebanyak 36 siswa (62\%) memilih pilihan salah (opsi C). Sebagian besar siswa beralasan "saat di $t=10$ posisi benda ada di 0 sehingga benda berhenti". Hal ini menunjukkan bahwa siswa masih belum bisa menghilangkan efek WYSYWIG dalam menginterpretasi grafik.

\section{Grafik Kecepatan terhadap Waktu}

Grafik kecepatan terhadap waktu disajikan pada butir soal nomor 3 sampai 7. Kemampuan siswa pada grafik kecepatan terhadap waktu ditinjau dari jumlah siswa menjawab benar mengalami peningkatan yang paling rendah dibanding kedua jenis grafik yang lain (Tabel 2). Salah satu contoh soal grafik kecepatan terhadap waktu disajikan pada gambar 2.

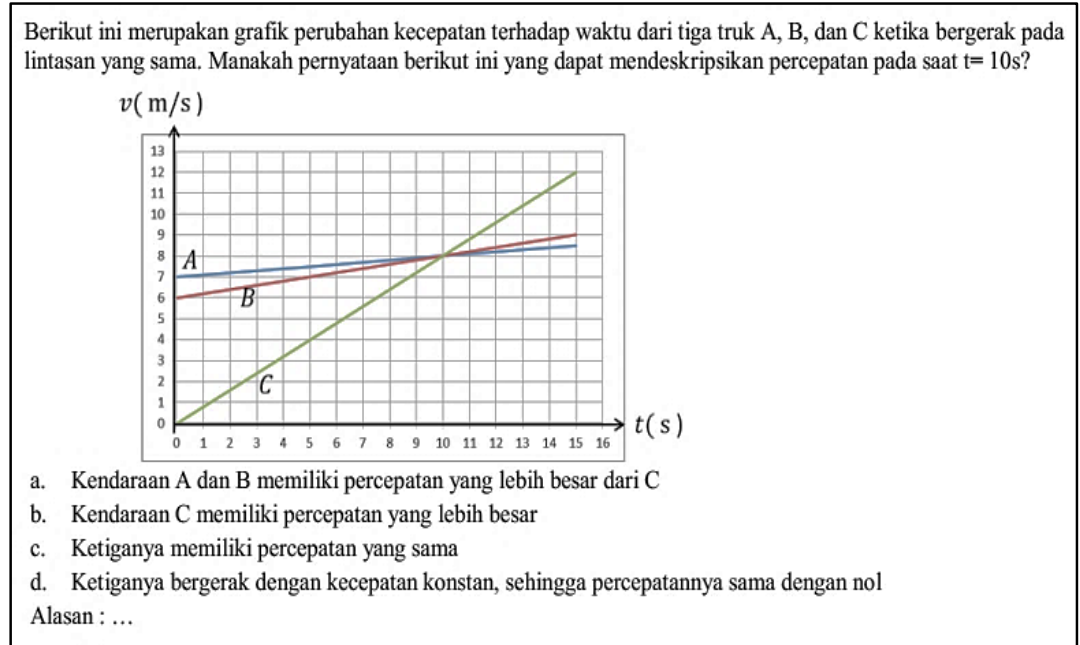

Gambar 2. Soal Grafik Kecepatan terhadap Waktu

Soal pada gambar 3 merupakan soal yang disajikan pada nomor 4. Jumlah siswa menjawab benar (opsi B) saat pretest sebanyak 29 siswa (50\%). Siswa yang menjawab benar memberi respons, yakni sebanyak tujuh siswa beralasan "garis kurva pada grafik $C$ bergerak naik dengan lintasan menanjak dan titik akhir berhenti di titik tertinggi atau terjauh". Satu orang yang lain beralasan "Meskipun grafik $C$ diawali dari kecepatan nol, dapat menyusul dengan cepat sehingga kecepatannya sama pada $t=10$ ”. Meskipun alasan yang disampaikan siswa kurang sesuai, namun dengan pemikiran tersebut siswa dapat menjawab benar.

Distribusi persentase siswa menjawab masing-masing pilihan jawaban, yaitu pilihan A 3\%, pilihan C 31\%, pilihan D $10 \%$, dan tidak menjawab 5\%. Pilihan jawaban $\mathrm{C}$ menjadi pilihan yang cukup banyak dipilih siswa. Siswa yang menjawab pilihan C sebanyak lima siswa beralasan bahwa "ketiga kendaraan berada pada titik yang sama yakni di $t=10 s$ ".

Pembelajaran grafik pada kinematika yang dilakukan mengajarkan siswa memberikan makna pada grafik. Siswa diajarkan untuk menghitung kemiringan dengan persamaan matematis pada grafik $x$ - $t$ dan $v$ - $t$. Selanjutnya, siswa diminta untuk mengecek hasil perhitungan dan diberikan penjelasan bahwa kemiringan grafik $x$ - $t$ menunjukkan besar kecepatan dan kemiringan grafik $v$ - $t$ menunjukkan percepatan. Pergeseran jawaban siswa setelah pembelajaran dapat dilihat pada tabel 4. 
Tabel 4. Tabulasi Silang Pergeseran Jawaban Siswa

\begin{tabular}{llllllc}
\hline & & \multicolumn{5}{c}{ Posttest } \\
\hline Pretest & & A & B* & C & D & Total Pretest \\
& A & 1 & 0 & 0 & 1 & 2 \\
& $\mathrm{~B}^{*}$ & 1 & 21 & 5 & 2 & 29 \\
& $\mathrm{C}$ & 2 & 13 & 2 & 1 & 18 \\
& $\mathrm{D}$ & 0 & 3 & 1 & 1 & 6 \\
& TM & 0 & 2 & 1 & 0 & 3 \\
\hline & Total Posttest & 4 & 39 & 9 & 5 & 58 \\
\hline
\end{tabular}

Setelah pembelajaran siswa menggeser jawaban ke pilihan B. Jumlah siswa menjawab benar saat posttest meningkat menjadi 39 siswa. Alasan siswa menjawab benar yakni "kurva pada grafik $C$ lebih curam dibandingkan grafik A dan B hal ini menunjukkan percepatan C lebih besar". Pada butir soal grafik kecepatan terhadap waktu terdapat dua soal yang mengalami penurunan jumlah siswa menjawab benar saat posttest (nomor 5 dan 7). Sebagai contoh soal nomor 7 disajikan pada gambar 3 berikut.

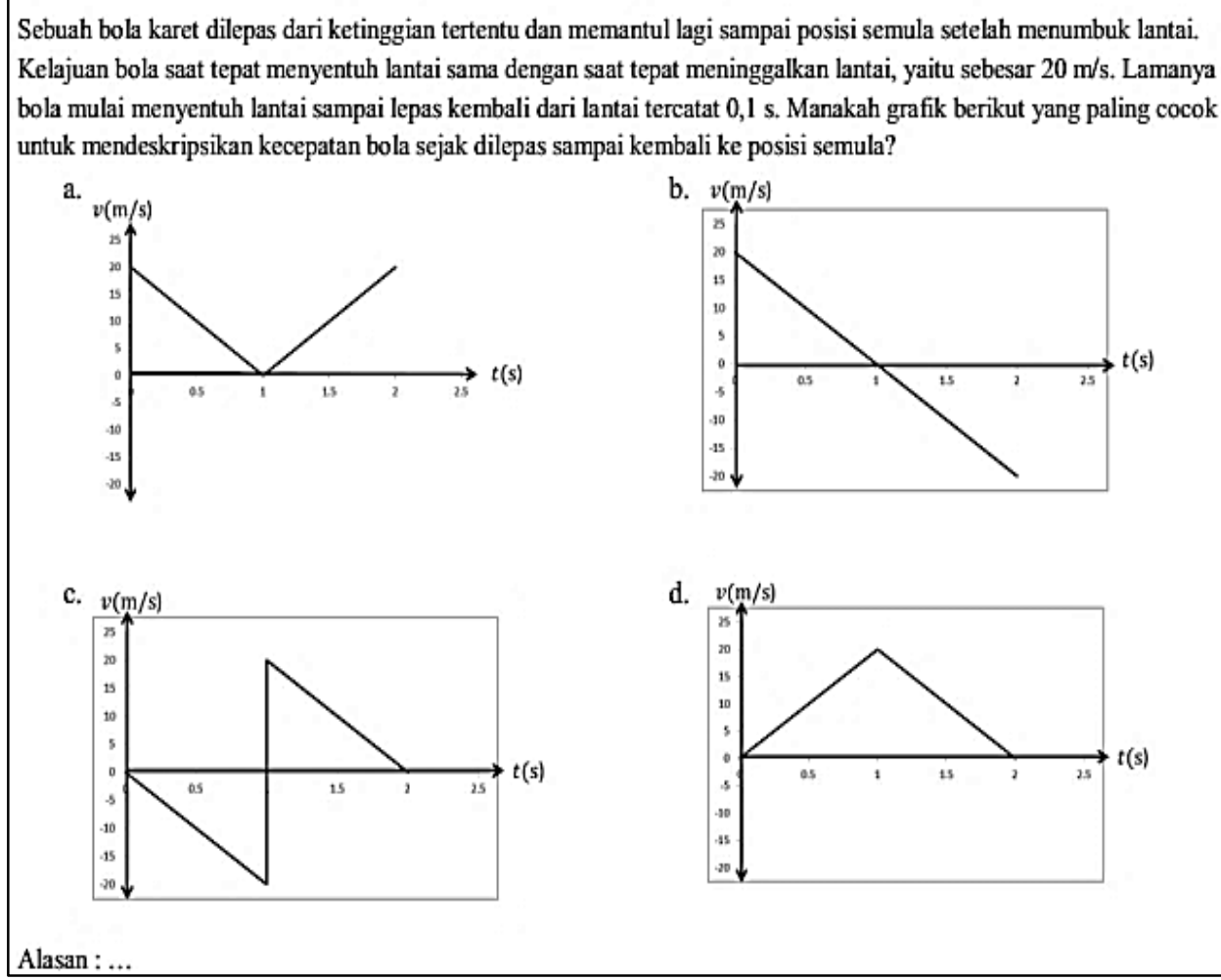

Gambar 3. Butir soal yang memuat grafik kecepatan terhadap waktu

Jumlah siswa yang menjawab pilihan benar (Opsi C) saat pretest sebanyak sembilan siswa (16\%). Tiga siswa memberikan alasan "grafik B sesuai dengan informasi data pada deskripsi soal" dan siswa lain tidak memberikan jawaban. Ketika posttest siswa menjawab benar menurun menjadi lima siswa (7\%). Hanya satu siswa yang mempertahankan pilihan pada opsi C. Pergeseran jawaban siswa setelah pembelajaran dapat dilihat pada tabel 5.

Tabel 5. Tabulasi Silang Pergeseran Jawaban Siswa

\begin{tabular}{|c|c|c|c|c|c|c|}
\hline & \multicolumn{6}{|c|}{ Posttest } \\
\hline & & $\mathbf{A}$ & B & $\mathbf{C}^{*}$ & D & Total Pretest \\
\hline \multirow[t]{6}{*}{ Pretest } & A & 12 & 2 & 2 & 4 & 20 \\
\hline & B & 0 & 1 & 0 & 1 & 2 \\
\hline & $\mathrm{C}^{*}$ & 3 & 0 & 1 & 5 & 9 \\
\hline & $\mathrm{D}$ & 10 & 2 & 2 & 6 & 19 \\
\hline & TM & 5 & 1 & 0 & 2 & 8 \\
\hline & Total Posttest & 30 & 5 & 5 & 18 & 58 \\
\hline
\end{tabular}


Siswa yang menjawab pilihan A memberikan respons "berdasarkan deskripsi jelas bahwa saat bola dijatuhkan posisi awal bola ada di atas kemudian ke bawah dan memantul lagi ke atas". Repsons jawaban siswa tersebut menunjukkan bahwa mereka mempunyai pemikiran deskripsi masalah tersebut jika dalam kenyataan sesungguhnya fenomenanya akan menjadi grafik pada pilihan A. Siswa menganggap gerakan benda bergerak melintasi sepanjang kurva grafik sehingga saat membaca informasi dari grafik, siswa langsung memberikan pernyataan sesuai dengan keadaan grafik. Pada kasus ini, siswa kesulitan menangkap informasi yang tersaji pada grafik sehingga untuk menjelaskan keadaan grafik masih mengalami kesulitan. Respons ini menunjukkan bahwa apa yang dilihat siswa sesuai dengan deskripsi maka seperti itulah jawabannya atau dikenal dengan istilah WYSIWYG (Elby, 2000). Siswa yang memiliki intuisi ini mengedepankan visual dengan membayangkan fenomena ke dalam realita.

Siswa yang memilih B menyatakan bahwa "terjadi perubahan arah saat memantul". Pilihan ini sudah mendekati pada konsep kecepatan yang mana merupakan besaran vektor sehingga dalam geraknya melihat arah juga. Siswa juga memahami bahwa perbedaan kurva yang melalui sumbu positif dan negatif memiliki perbedaan arah gerak. Siswa selama pembelajaran siswa mulai terbiasa menerapkan arah untuk kecepatan. Namun, kesalahan siswa terletak pada skala yang tertera pada grafik.

Jawaban lain yang banyak dipilih siswa adalah pilihan D dengan respons menjawab "saat benda dijatuhkan dari ketinggian tertentu kecepatan awal benda adalah nol semakin ke bawah semakin tinggi dan setelah memantul kecepatannya seperti kecepatan awal". Konsep ini merupakan konsep yang benar untuk mengidentifikasi gerak benda pada fenomena nomor 7. Namun, siswa melupakan arah kecepatan yang seharusnya juga diidentifikasi untuk membuat grafik kecepatan terhadap waktu.

\section{Grafik Percepatan terhadap Waktu}

Butir soal yang memuat grafik percepatan terhadap waktu disajikan pada soal nomor 8 dan 9. Jumlah siswa menjawab benar meningkat dari pretest ke posttest (Tabel 2). Sebagai contoh soal nomor 8 disajikan pada gambar 4.

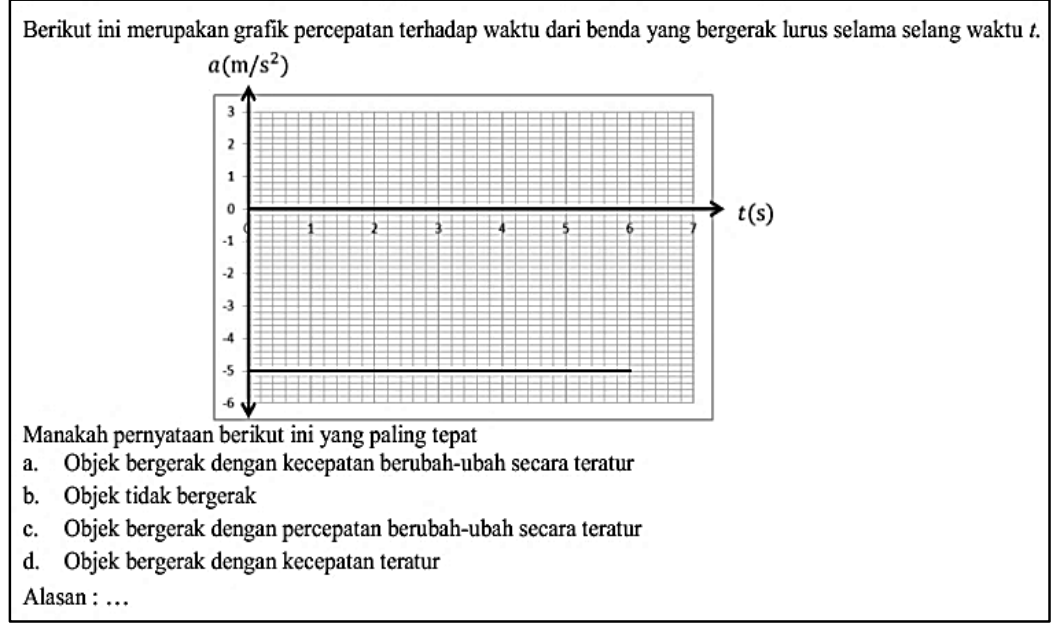

Gambar 4. Butir soal yang memuat grafik percepatan terhadap waktu

Jumlah siswa menjawab pilihan benar sebanyak sembilan siswa (16\%) saat pretest. Satu siswa memberikan alasan "bentuk grafik lurus ke kanan", dua siswa memberikan alasan "percepatan konstan sebesar $-5 \mathrm{~m} / \mathrm{s}^{2}$ " dan selebihnya tidak memberikan alasan. Kedua alasan tersebut diperoleh siswa dengan menganalisis grafik yang disajikan. Analisis yang dipakai terpengaruh dengan efek WYSYWIG (Elby, 2000), meski sudah cukup baik siswa dapat menangkap informasi besar percepatan setiap waktu dari grafik. Distribusi pilihan yang dipilih siswa yakni opsi B 5\%, opsi D 76\% dan tidak menjawab 3\%. Siswa yang memilih pilihan D sebanyak 28 siswa beralasan "kecepatan benda konstan grafiknya lurus tidak berubah". Hasil pemikiran siswa menandakan siswa tidak benar-benar mengerti perbedaan antara kecepatan dan percepatan. Pergeseran jawaban siswa setelah pembelajaran dapat dilihat pada tabel 6.

Tabel 6. Tabulasi Silang Pergeseran Jawaban Siswa

\begin{tabular}{llllllc}
\hline & & \multicolumn{7}{c}{ Posttest } \\
\hline Pretest & A $^{*}$ & B & C & D & Total Pretest \\
& & 7 & 1 & 0 & 1 & 9 \\
& B & 0 & 0 & 0 & 3 & 3 \\
& D & 14 & 1 & 2 & 27 & 44 \\
& TM & 2 & 0 & 0 & 0 & 2 \\
\hline & Total Posttest & 23 & 2 & 2 & 31 & 58 \\
\hline
\end{tabular}


Siswa menjawab benar saat posttest menjadi 23 siswa (40\%). Siswa lebih mudah menginterpretasikan makna grafik percepatan terhadap waktu karena telah memiliki pengalaman selama pembelajaran. Saat pembelajaran siswa diminta untuk menggambarkan grafik percepatan pada gerak lurus beraturan dan gerak lurus berubah beraturan sehingga siswa lebih mudah mengenali dan mendeskripsikan grafik percepatan terhadap waktu.

Ditinjau dari keseluruhan butir soal yang diujikan pada siswa untuk bekerja dengan grafik pada kinematika siswa mulai terbiasa dengan grafik setelah pembelajaran. Siswa juga menganggap bekerja dengan grafik pada kinematika merupakan pengalaman yang baru terlepas dari grafik yang biasa didapatkan dalam matematika. Siswa lebih mudah untuk mengenali grafik yang besarnya tetap ataupun bergerak naik secara konstan. Jika dalam suatu grafik tersaji kurva campuran siswa masih kesulitan menginterpretasikan dan membaca grafik tersebut. Sangat penting bagi pengajar untuk membiasakan siswa membaca dan memaknai grafik terlebih dahulu.

\section{SIMPULAN}

Pentingnya grafik dalam menyampaikan informasi maupun konteks penting dalam menginterpretasikan suatu data terkadang seringkali kurang diperhatikan. Siswa akan cenderung menghadapi kesulitan untuk memaknai dan mendeskripsikan informasi dari grafik. Grafik yang dipelajari pada kinematika dapat dijadikan pengembangan dan aplikasi pengetahuan grafik yang dimiliki siswa pada matematika. Kesalahan-kesalahan siswa dalam memaknai grafik dapat diperbaiki melalui pembelajaran kinematika. Meskipun tidak seluruhnya memberikan hasil yang meningkat, secara umum sudah mampu membantu siswa untuk memperbaiki dan meningkatkan kemampuan siswa menggunakan representasi grafik. Perlu diterapkannya pembelajaran yang dapat menekankan dan melatih siswa untuk membuat representasi grafik. Langkah awal yang dapat dilakukan yakni dengan membiasakan siswa mengenali dan membaca grafik.

\section{DAFTAR RUJUKAN}

Beichner, R. J. (2014). Testing Student Interpretation of Kinematics Graphs. American Journal of Physics, 62(8), 750-762. https://doi.org/10.1119/1.17449

Bollen, L., De Cock, M., Zuza, K., Guisasola, J., \& van Kampen, P. (2016). Generalizing a Categorization of Students' Interpretations of Linear Kinematics Graphs. Physical Review Physics Education Research, 12(1). https://doi.org/10.1103/PhysRevPhysEducRes.12.010108

Ceuppens, S., Bollen, L., Deprez, J., Dehaene, W., \& De Cock, M. (2019). 9th Grade Students' Understanding and Strategies when Solving x (t) Problems in 1D Kinematics and y (x) Problems in Mathematics. Physical Review Physics Education Research, 15(1). https://doi.org/10.1103/PhysRevPhysEducRes.15.010101

Christensen, W. M., \& Thompson, J. R. (2012). Investigating Graphical Representations of Slope and Derivative without a Physics Context. Physical Review Special Topics - Physics Education Research, 8(2). https://doi.org/10.1103/PhysRevSTPER.8.023101

Elby, A. (2000). What Students' Learning of Representations Tells us about Constructivism. The Journal of Mathematical Behavior, 19(4), 481-502. https://doi.org/10.1016/S0732-3123(01)00054-2

Hake, R. R. (2008). Interactive-Engagement Versus Traditional Methods: A Six-Thousand-Student Survey of Mechanics Test Data for Introductory Physics Courses. American Journal of Physics, 66(1), 64-74. https://doi.org/10.1119/1.18809

Hale, P. (2000). Kinematics and Graphs: Students' Difficulties and CBLs. The Mathematics Teacher, $93(5), 4$.

McDermott, L. C., Rosenquist, M. L., \& Zee, E. H. V. (2006). Student Difficulties in Connecting Graphs and Physics: Example from Kinematics. American Journal of Physics, 55(6). https://doi.org/10.1119/1.15104

McPadden, D., \& Brewe, E. (2017). Impact of the second semester University Modeling Instruction course on students' representation choices. Physical Review Physics Education Research, 13(2). https://doi.org/10.1103/PhysRevPhysEducRes.13.020129

Morgan, G. A., Leech, N. L., Gloeckner, G. W., \& Karen C. Barrett. (2004). SPSS for Introductory Statistics: Use and Interpretation. London: Lawrence Erlbaum Associates, Inc.

Nguyen, D. H., \& Rebello, N. S. (2011). Students' Understanding and Application of the Area Under the Curve Concept in Physics Problems. Physical Review Special Topics - Physics Education Research, 7(1). https://doi.org/10.1103/PhysRevSTPER.7.010112

Nixon, R. S., Godfrey, T. J., Mayhew, N. T., \& Wiegert, C. C. (2016). Undergraduate Student Construction and Interpretation of Graphs in Physics Lab Activities. Physical Review Physics Education Research, 12(1). https://doi.org/10.1103/PhysRevPhysEducRes.12.010104

Planinic, M., Milin-Sipus, Z., Katic, H., Susac, A., \& Ivanjek, L. (2012). Comparison of Student Understanding of Line Graph Slope In Physics and Mathematics. International Journal of Science and Mathematics Education, 10(6), 1393-1414. https://doi.org/10.1007/s10763-012-9344-1

Susac, A., Bubic, A., Kazotti, E., Planinic, M., \& Palmovic, M. (2018). Student understanding of graph slope and area under a graph: A comparison of physics and nonphysics students. Physical Review Physics Education Research, 14(2). https://doi.org/10.1103/PhysRevPhysEducRes.14.020109 
309 Jurnal Pendidikan, Vol. 4, No. 3, Bln Maret, Thn 2019, Hal 302-309

Wemyss, T., \& van Kampen, P. (2013). Categorization of First-Year University Students' Interpretations of Numerical Linear Distance-Time Graphs. Physical Review Special Topics - Physics Education Research, 9(1). https://doi.org/10.1103/PhysRevSTPER.9.010107

Zucker, A., Kay, R., \& Staudt, C. (2013). Helping Students Make Sense of Graphs: An Experimental Trial of SmartGraphs Software. 23(3). https://doi.org/10.1007/s10956-013-9475-3 